\title{
Valuation of construction work on architectural heritage and its influence on project implementation decision
}

\author{
Lucie Brožová ${ }^{1}$, Iveta Střelcová ${ }^{1}$, Stanislav Vitásek ${ }^{1,}$ Radan Tomek $^{1}$ and Tomáš Krulický ${ }^{2 *}$ \\ ${ }^{1}$ Czech Technical University in Prague, Faculty of Civil Engineering, Thákurova 7, Prague 6, Czech \\ Republic \\ ${ }^{2}$ Institute of Technology and Business in České Budějovice, School of Expertness and Valuation, \\ Okružní 517/10, 37001 České Budějovice, Czech Republic
}

\begin{abstract}
The article deals with the description of the methodology for determining the prices of construction work used most often in the reconstruction of historic buildings. The procedure is based on parametric estimating of buildings and on traditional tools and principles of pricing. The historic building is divided into structural parts and technological units. Structural elements are individually valued at the unit price, which was created on the basis of sub-budget. Very strict rules are set for the financing of cultural monuments and the method of valuation is based on the price systems' methodology. The research also included an analysis of market prices and a subsequent comparison with indicative prices. Proper estimate of historic buildings' reconstruction cost is also an important input for the decision-making process regarding the actual implementation of the project, its method of execution and its life cycle cost determination.
\end{abstract}

Keywords: cultural monument, historical objects, valuation of reconstructions, parametric valuation, price analysis

\section{Introduction}

Preservation of cultural monuments is one of the important ways to get to know our past. Caring for them is not an easy task, but it is the crucial one for the National Monuments Institute (NPÚ). A significant part of this care is the restoration and maintenance of architectural monuments. It is therefore necessary to pay considerable attention to the economic aspect of this care, specifically in terms of valuation. The uniqueness of every such cultural monument and the emphasis on the delicate way of intervention make it difficult to value such buildings. Each cultural monument requires a different degree of intervention, and each element that appears in the monument should be treated as unique. Valuation of reconstructions of historic buildings is problematic both in the phase of the first cost estimates and in the creation of the itemized budget of the reconstruction. The biggest problem in both cases is the high specificity and uniqueness of the objects. It is

\footnotetext{
*Corresponding autor: krulicky@mail.vstecb.cz
} 
important to establish methodologies that contribute to full recovery and prevent the use of inappropriate materials and workflows, which is still occasionally happening.

The aim of this article is to outline the method of valuing construction work on historic buildings in the phase of the first cost estimates, as well as in creating an itemized budget for reconstruction. The proposed methodology is based on an analysis of market prices of construction work most often performed during repairs of historic buildings.

Proper estimate of historic buildings' reconstruction cost is also an important input for the decision-making process regarding the actual implementation of the project. It also helps to predict its life cycle cost and to reduce risks during the reconstruction works.

\section{Literature Review}

The issue of valuing construction work on immovable cultural monuments has not yet been addressed in more depth in the professional literature. There are many publications that deal with the preservation of cultural heritage objects, but they usually do not address construction costs and other economic aspects $[1,2,3]$.

Many authors also study 3D modelling of historic buildings [4, 5, 6]. However, the economic aspect and the calculation of construction costs lag behind.

In construction, estimation of costs is important for both the investor who finances the investment and the contractor who has to estimate the costs and achieve a level of profit.

To determine the price of construction works, we have to know the direct and indirect costs, so that the contractors can estimate costs of works based on the unit price. This method requires a lot of experience from the contractor. The unit price must include all of the mentioned cost's elements. Traditional method of cost estimating is based on calculation of separate costs elements: the direct cost (labour, materials, and equipment), indirect cost and profit analyze article[7].

The cost estimating in construction is the main topic of the article by Bernhard Bauer et al. [8]. According to the authors, each cost estimate has peculiarities and has to be adapted for each project. The better the project documentation, the more accurate the cost estimate and price determination.

The article by Radovan Majer et al [9] also deals with the issue of estimating in construction. The article targets the methods of profit calculation, because budgetary factors are frequent cause of business failure in construction.

The link between building life and life cycle costs is analysed by Heralová [10]. Macek [11] in detail analyzes the costs of real estate maintenance. Karásek [12] also dealt with life cycle maintenance cost planning. Heralová et al. [13] deals with the issue of maintenance and renovation of cultural heritage objects. This is a very specialised area of cost optimization.

The reconstruction of the cultural monuments can also be seen as an investment into the historical substance of the region. From the economic point of view, it can provide new benefits as Dlask and Beran [14] claim.

The procedures leading to the creation of sub-budgets (i.e. few aggregated estimates) and budgets for the structural elements of historical buildings were applied by the External Thermal Insulation Composite System (ETICS) by Dlask et al. [15]. For unique historical structures, it is possible to separate selected items and use them in budgeting.

Vrbka et al. [16] focuses on the synthesis of valuation methods that determine the total amount of investment. Hromada et al. [17] deals with the description of the methodology for calculating the reproduction value of buildings.

Macek et al. [18] wrote the article about the issue of maintenance and renovation of cultural heritage objects and about the cost optimization. 


\section{Valuation of construction work on architectural heritage}

Valuation of construction work on immovable cultural monuments methodically on the valuation of construction activities related to historic buildings. The uniqueness of individual historical building's elements causes higher demands on the technologies used in comparison with classic (modern) building structures during their revitalization. Therefore, the valuation proposal itself is based on an analysis of market prices for construction work used in historic buildings in combination with traditional tools and pricing methods for the regular ones.

The valuation methodology is based on seven pillars:

- Price systems for buildings.

- Budgetary principles.

- Individual estimates of items using a standard estimating formula.

- Hourly billing rates.

- Principles of parametric valuation of buildings and division of structural elements respecting the needs of immovable cultural monuments.

- Sub-estimates in relation to defined structural elements.

- Analysis of market prices for construction work used in historic buildings.

\subsection{Price systems for buildings}

The price system is a comprehensive database on assembly and construction work, building materials and products. It includes information systematically classified into items. These individual items consist of an identifier (code), a description and a unit of measure, supplemented by price and technical conditions intended for the calculation of necessary costs and the calculation of the unit price. The reported values in the price systems are obtained by statistical methods from the data of the respondents (usually real companies' bid prices from recent tenders) in the structure of the estimating formula.

Usually, each country has its own national classification system or at least the usual structure for classifying building structures and works. In the Czech construction environment, it is the Classification of Building Structures and Works (TSKP) on which the price systems issued by private engineering companies are based.

Price systems are primarily intended for the needs of building construction. However, they also have their use for the line constructions, where they are applied for construction projects that are not financed by the State Fund for Transport Infrastructure (SFDI), but by other public contracting authorities (regions, municipalities, etc.). These are usually simplier objects, such as third-class roads, culverts, footbridges, etc. [19]

\subsection{Budgetary principles by price system}

For the valuation of construction work on immovable cultural monuments, we use the TSKP classification. The TSKP classification is based on construction parts (Main Construction Production (HSV), i.e. underground construction plus framework; Associated Construction Production (PSV), also known as work trades; and assembly price lists (M price lists). Specifically, for construction work related to demolition or repairs in the HSV construction work, separate catalogs (price lists) intended for demolition and repairs and maintenance are used. Conversely, in associated construction output, items for valuing these activities are part of individual catalogs. They are divided into individual parts:

- Part A - Establishment of structures.

- Part B - Demolition (disassembly) of structures.

- $\quad$ Part C - Repair and maintenance of structures. 
Demolition prices include costs arising from a specific construction activity, including putting rubble on a pile or loading it onto a truck. It is also necessary to consider the technological handling of rubble at the level of in-site transport of rubble and demolished materials and off the site, i.e. the removal of rubble and demolished materials to the landfill, including the landfill fee.

The prices of intra-site transport of rubble and demolished materials include costs:

- For horizontal transport either by carrying or using a construction wheel or using a conveyor.

- For vertical transport:

- with the use of mechanization-crane, construction elevator, or even a construction winch

- $\quad$ with limited mechanization - without the use of a crane, i.e. only with a construction lift or winch

- hand-carried on stairs.

The method of measurement for individual demolished structures is based on its volume, e.g.: for walls, foundations, columns, pillars, ceilings, the quantity is calculated in $\mathrm{m} 3$ of the volume of structures into which the entire structure is decomposed for estimating purposes, e.g.:

- The volume of masonry with insulating cavities is considered including cavities.

- For demolition of half-timbered masonry or masonry into a steel frame, the prices of demolition of the relevant type of masonry can be used and for these construction activities the volume of the wooden or steel structure is not deducted.

On the other hand, there are demolished structures that are not included in the total volume, e.g.:

- volume of window openings,

- volume of door openings,

- volume of niches, if the visible area of individual niches is greater than $0.5 \mathrm{~m} 2$ and at the same time the depth is greater than $0.15 \mathrm{~m}$,

- volume of chimneys, ventilation and other vents with their cross-section greater than $0.05 \mathrm{~m} 2$,

- volume of protrusions lower than $50 \mathrm{~mm}[20]$.

\subsection{Individual estimation of items using a standard estimating formula}

Individual estimates target direct costs for determining own costs or for creating a price in cost components with respect to specific conditions, technology and organization of production, place, time. The basis for determining the price of a building for most types of company prices is the estimation of costs of individual structures and works. In many cases, before this estimate, the costs of individual cost components must be estimated due to individual conditions (items of the so-called estimating formula - see the picture below). Individual estimate presupposes clarity of technologies, construction conditions, built information system regarding prices and own costs, own normative basis for determining consumption, perfectly performed preparation with regard to construction risks, estimation of business risks and changes in prices and other input conditions over time and finally skilled estimators with a sense of company's capabilities and situation of the market. 
The costs for the implementation of a certain construction activity, which are directly related to its implementation, are estimated for the so-called estimating unit. The estimating unit is defined as the output defined by the name, qualitative or delivery conditions and unit of measure. The estimating unit can be a building object or its part, individual construction work or structure, assembly work, man-hour, etc [21].

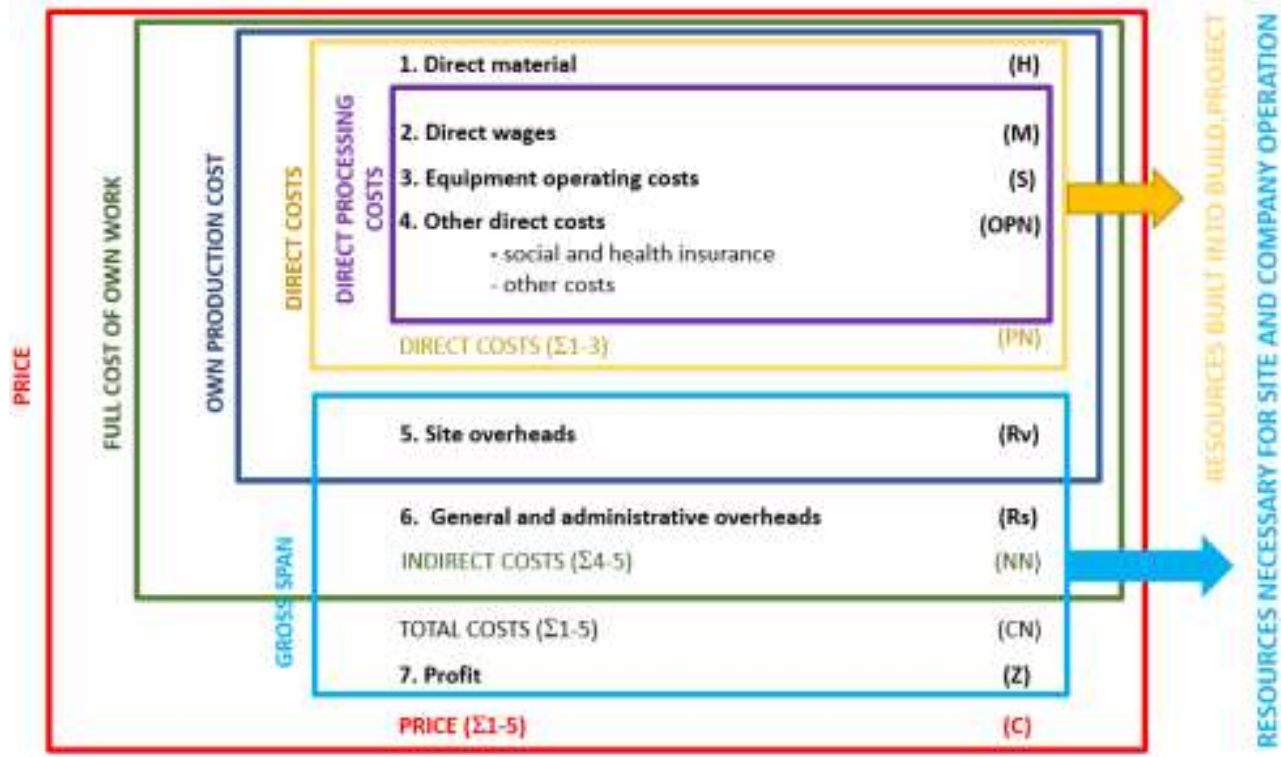

Figure 1. Estimating formula

Source: Own processing.

\subsection{Hourly billing rate}

We use it where it is difficult to determine the output per unit of production (unit of measure is either $\mathrm{m} 2, \mathrm{~m} 3, \ldots .$.$) . Above all, it is a matter of determining the costs of$ restoration work, for which it is not possible to determine their extent in advance (e.g. work on stucco elements or facade, renaissance cornice or such).

Hourly billing rate includes:

- Labor costs, including levies, costs of small materials, basic equipment for a specific activity, overheads, profit.

Hourly billing rate does not include:

- Costs for restoration materials, for machines, are mainly rental of machines, transport costs, scaffolding, demolition and construction site equipment.

\subsection{Principles of parametric valuation of buildings and division of structural elements}

Parametric valuation of buildings is a method based on estimating construction costs using selected or input parameters (basic dimensional quantities) of the building. Another fundamental prerequisite is the division of a building into structural and technological units (referred to as structural elements), which are directly linked to selected input parameters (e.g. width, length and height of the building). 
Structural elements are individually valued on a defined estimating unit (usually a common unit of measure from budgeting practice). The valuation itself can be done in two ways. It is either the use of available price systems or the application of prices from the market, which are obtained by the company on the basis of the implementation of previous construction projects transformed to the required price level. The application of market prices is a more accurate method of valuation, but it requires the company to have both a uniform way of collecting information on costs in relation to structural elements, and a system for monitoring trends and predicting price developments.

The final estimate of construction costs will be created by the sum of valued individual structural elements that are part of the subjected historic building.

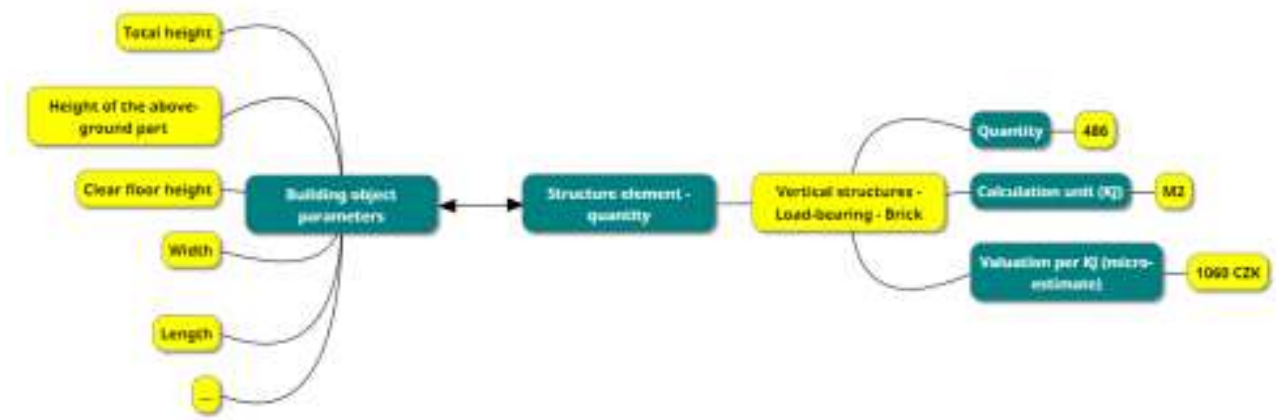

Figure 2. The link between the parameters of the building and the brickwork structural element Source: Own processing.

The advantage of parametric valuation lies in the rapid determination of costs for construction work based on selected technical information about the building. Nevertheless, this method of valuation is not completely common in the Czech Republic. Price (budget) indicators are closest to this valuation method. However, these indicators do not reflect as many input parameters about the building as the parametric valuation method does, so they are less accurate. An example of a complete classification according to the proposed structure of the division is shown below in the figure for vertical load-bearing masonry structural elements. 


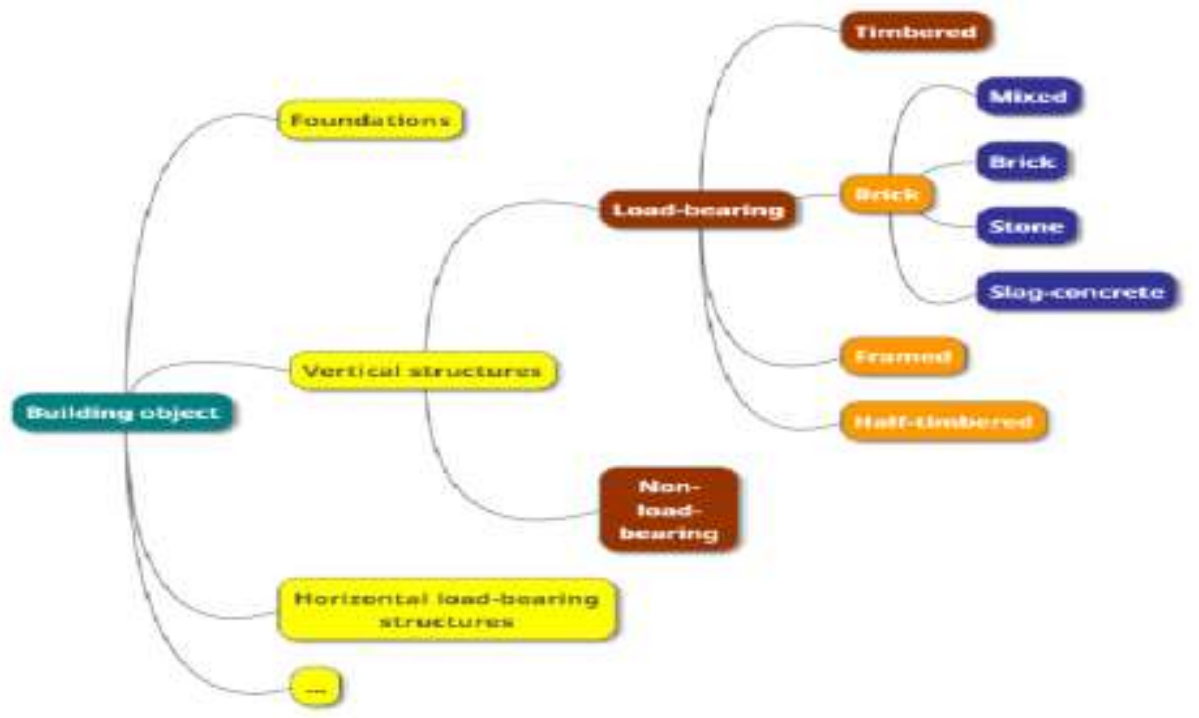

Figure 3. Example of hierarchical division for vertical load-bearing masonry structural elements Source: Own processing.

\subsection{Sub-estimate of structural elements}

The unit price, which is assigned to the defined structural elements, is based on the principle of the so-called sub-estimate. It consists of several items of the CS ÚRS price system (currently at price level II / 20), where the unit price of a structural element is created by the sum of partial prices (so-called indicative prices in the structure of the estimating formula) for all sub-estimate's items. The estimating unit of the sub-estimate corresponds to the usual unit of measure of the structural element. In each sub-estimate, there are type items of these activities:

- Demolition of the existing structure

- demolition of the structure,

- intra-site relocation of rubble,

- removal of rubble to the construction dump,

- rubble deposit fee,

- Creation of a new structure

- new construction, including surcharges,

- Internal \& external scaffolding (according to the position of the structure)

- auxiliary scaffolding,

- facade scaffolding,

- assembly,

- disassembly,

- rent (surcharge),

- Material transfer

- transfer of materials from the site depot to the place of the structure's construction.

The following table shows an example of creating a sub-estimate for demolition and subsequent construction of a masonry partition made of ceramic bricks without surface treatment [22]. 
Table 1. Sub-estimate of vertical non-load-bearing structure element - brick partitions, ceramic, without surface treatment, unit price of $2173 \mathrm{CZK} / \mathrm{m} 2$

$3 \quad$ Vertical and complete construction 935,90

\begin{tabular}{|l|l|l|r|r|r|r|}
\hline 1 & 342241162 & $\begin{array}{l}\text { Partitions made of bricks full length } 290 \mathrm{~mm} \\
\text { strength P 15 on MC } 140 \mathrm{~mm} \text { thick }\end{array}$ & $\mathrm{m} 2$ & 1.000 & 745.00 & 745.00 \\
\hline 2 & 342291121 & $\begin{array}{l}\text { Anchoring of partitions to load-bearing } \\
\text { structures }\end{array}$ & $\mathrm{m}$ & 1.000 & 108.00 & 108.00 \\
\hline 3 & 346971132 & $\begin{array}{l}\text { Insulation under partitions against sound } \\
\text { spreading, double, made of sand, cardboard } \\
\text { and MC width up to } 200 \mathrm{~mm}\end{array}$ & $\mathrm{~m}$ & 1.000 & 82.90 & 82.90 \\
\hline
\end{tabular}

9

Other construction and work, demolition

410.63

\begin{tabular}{|c|l|l|r|r|r|r|}
\hline 4 & 949101111 & $\begin{array}{l}\text { Scaffolding of auxiliary height of scaffolding } \\
\text { floor up to 1.9 m }\end{array}$ & $\mathrm{m} 2$ & 1.200 & 47.80 & 57.36 \\
\hline 5 & $\begin{array}{l}962031133- \\
1\end{array}$ & $\begin{array}{l}\text { Cutting of partitions from fired, solid, hollow } \\
\text { bricks }\end{array}$ & $\mathrm{m} 2$ & 1.000 & 114.00 & 114.00 \\
\hline 6 & 998017003 & $\begin{array}{l}\text { Movement of materials with limited } \\
\text { mechanization for buildings up to 24 m of } \\
\text { height }\end{array}$ & $\mathrm{t}$ & 0.235 & 1020.00 & 239.27 \\
\hline
\end{tabular}

997

Moving rubble

826.60

\begin{tabular}{|l|l|l|r|r|r|r|}
\hline 7 & 997013155 & $\begin{array}{l}\text { In-site transport of rubble and demolished } \\
\text { materials for buildings up to 18 m of height } \\
\text { with limited mechanization }\end{array}$ & $\mathrm{t}$ & 0.261 & 1630.00 & 425.43 \\
\hline 8 & 997013501 & $\begin{array}{l}\text { Transport of rubble and demolished materials } \\
\text { to a landfill or intermediate landfill up to 1 } \\
\text { km with the composition }\end{array}$ & $\mathrm{t}$ & 0.261 & 233.00 & 60.81 \\
\hline 9 & 997013509 & $\begin{array}{l}\text { Surcharge for the removal of rubble and } \\
\text { demolished materials to the landfill ZKD 1 } \\
\text { km over 1 km }\end{array}$ & $\mathrm{t}$ & 2.349 & 10.45 & 24.55 \\
\hline \multicolumn{7}{|c|}{$\begin{array}{l}\text { 0.2610 * 9 Recalculated by the quantity } \\
\text { coefficient }\end{array}$} \\
\hline 10 & 997013631 & $\begin{array}{l}\text { Landfill fee (landfill) for construction waste } \\
\text { mixed waste code 170 904 }\end{array}$ & $\mathrm{t}$ & 0.261 & 1210.00 & 315.81 \\
\hline
\end{tabular}

Source: Own processing, based on CS ÚRS price system.

\section{Analysis of market prices for construction work used in historic buildings}

Due to the complexity of valuing construction works, repairs and reconstructions of historic buildings, a comparison of indicative and bid prices for completed constructions was performed. This comparison was made on 16 bid budgets for the reconstruction of historic buildings located in several regions of the Czech Republic, specifically the Pardubický, Plzeňský, Královehradecký, Středočeský, Moravskoslezský, Ústecký, Jihomoravský, Jihočeský and Vysočina.

The comparison of indicative and bid prices was performed on a file that contains 464 representative items from 16 bid budgets. These items were defined by the CS ÚRS price system. The comparison included not only individual work items (R-items), but also items that specify the delivery of a material or product. These items are mainly of the list of works of the Associated Construction Production (PSV).

Construction works on historic buildings took place at different times - from the 2nd quarter of 2013 to the 2 nd quarter of 2019. In contrast, the indicative prices (IP) of the CS ÚRS price system with which the bid prices (BP) were compared were in the current price level of the 1 st quarter of 2021. In order for these bid prices to be comparable with the 
indicative prices, it was necessary to unify the price level for all prices for the 1 st quarter of 2021 using coefficients. Data published by the Czech Statistical Office (ČSÚ) were used to determine these coefficients.

Every quarter, the ČSÚ publishes a publication entitled "Construction Work Price Indices, Construction Work Price Indices and Construction Production Cost Indices". The publication contains several tables in which the percentage development of prices compared to the previous period is recorded.

To determine the development of prices of construction work for individual sections and trades, we use the table Price indices of construction structures and work according to TSKPstat, which has the following breakdown (see Picture 4 below).

\begin{tabular}{|c|c|}
\hline TSKe? code & name \\
\hline & Coesstruction and work of HSV \\
\hline \multirow[t]{2}{*}{1} & Larthwoworks \\
\hline & of which: \\
\hline 12 & Excavations and og-througs \\
\hline 13 & Dug excsuations \\
\hline 16 & Rebcation of the excevation \\
\hline 17 & Seit cenatruction \\
\hline \multirow[t]{2}{*}{2} & Foundation, strengthening of rocks \\
\hline & of which: \\
\hline 27 & Besaics \\
\hline \multirow[t]{2}{*}{3} & Vertical and compleie structures \\
\hline & of which: \\
\hline 3t & Wals of baidnges \\
\hline 33 & Coluens and plitars \\
\hline 34 & Wels and partions \\
\hline \multirow[t]{2}{*}{4} & foricontal structures \\
\hline & of which: \\
\hline $4 \mathrm{t}$ & Celings and deling structures of bukings \\
\hline \multirow[t]{2}{*}{6} & Communication \\
\hline & of which: \\
\hline Se & Base layeis of rosds, arports and areas \\
\hline 57 & Covers of cosss, arports and areas of agpregste or blumen \\
\hline 58 & Covers of roads, arports and areas of concrets and ather materials \\
\hline 59 & Covers of rosss, arports and paved areas \\
\hline \multirow[t]{2}{*}{ s } & Surface treatment, fleoring and installation of nilings \\
\hline & not $\quad$ ing \\
\hline et & Treatment of interior aurfaces. \\
\hline 62 & Wodifcabion of extemai nurtaces \\
\hline 63 & Floors and foor constructians \\
\hline \multirow[t]{2}{*}{ a } & Long-distance and connecting lines \\
\hline & of which \\
\hline 87 & Fasilc and glass pipes \\
\hline \multirow[t]{2}{*}{9} & Other construction and work, demolition \\
\hline & of which \\
\hline 94 & Scaffoising and constructian ifts \\
\hline 36 & Denciton of structures \\
\hline 97 & Punching heles and ther Jenoltion work \\
\hline 99 & Moss transfer and debris handing \\
\hline
\end{tabular}

\begin{tabular}{|c|c|}
\hline TSK.P code & name \\
\hline 7 & Construction and work of PSV \\
\hline \multirow[t]{2}{*}{71} & Insulation \\
\hline & nei- \\
\hline 711 & Insulation against waber, meianure and gas \\
\hline 712 & Insulation - costings \\
\hline 713 & Thermsi insuatnn \\
\hline \multirow[t]{2}{*}{72} & Sanitary technical inatailations. \\
\hline & nei: \\
\hline 721 & Sentitary tectirical nstalations - sewerage \\
\hline 722 & Smzary techinicai instalations - water aupply \\
\hline 723 & Santary technical inatalabons - gas ppelne \\
\hline 725 & Sentiary technical instakations - Sotures \\
\hline \multirow[t]{2}{*}{73} & Central heating \\
\hline & of which \\
\hline 733 & Centres heating - detrtution spes \\
\hline 734 & Central bating - Enings: \\
\hline 735 & Central Neating - radiators \\
\hline \multirow[t]{2}{*}{74} & Electrical equipment \\
\hline & Ind: \\
\hline 743 & Electricai equpent - rough assembly \\
\hline 744 & Electrical equpnent - wrng \\
\hline 747 & Electrical equipnent - sssembly of power squpment \\
\hline 76 & Technological equipment \\
\hline \multirow[t]{2}{*}{76} & 5tructures \\
\hline & of which \\
\hline 762 & Cexpentry strectures \\
\hline 763 & Mountad stnuctures \\
\hline 764 & Pumbing structures \\
\hline 785 & Hard roofing structures \\
\hline 766 & Jainery structures \\
\hline 767 & Locksnth structures \\
\hline 768 & Sleel structures \\
\hline \multirow[t]{2}{*}{$\pi$} & Floars \\
\hline & incl: \\
\hline $7 \pi$ & The foors \\
\hline 772 & Stwoe feors \\
\hline 775 & Foided floors \\
\hline 776 & Coating fleors \\
\hline 777 & Cust Foses \\
\hline \multirow[t]{2}{*}{78} & Finishing job \\
\hline & nd: \\
\hline 781 & Finiahing work - theng \\
\hline 783 & Finiahing work - ceatings \\
\hline 784 & Finiahing work- kurfacs painting \\
\hline
\end{tabular}

Figure 4. Classification of building structures and works according to TSKP Source: Czech Statistical Office (ČSÚ).

The distribution of individual items into the HSV and PSV sections (according to the division of the TSKP based on the CS ÚRS price system) is evident from the following figures (Figure 5). 


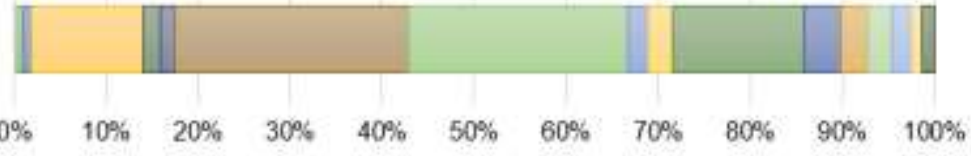

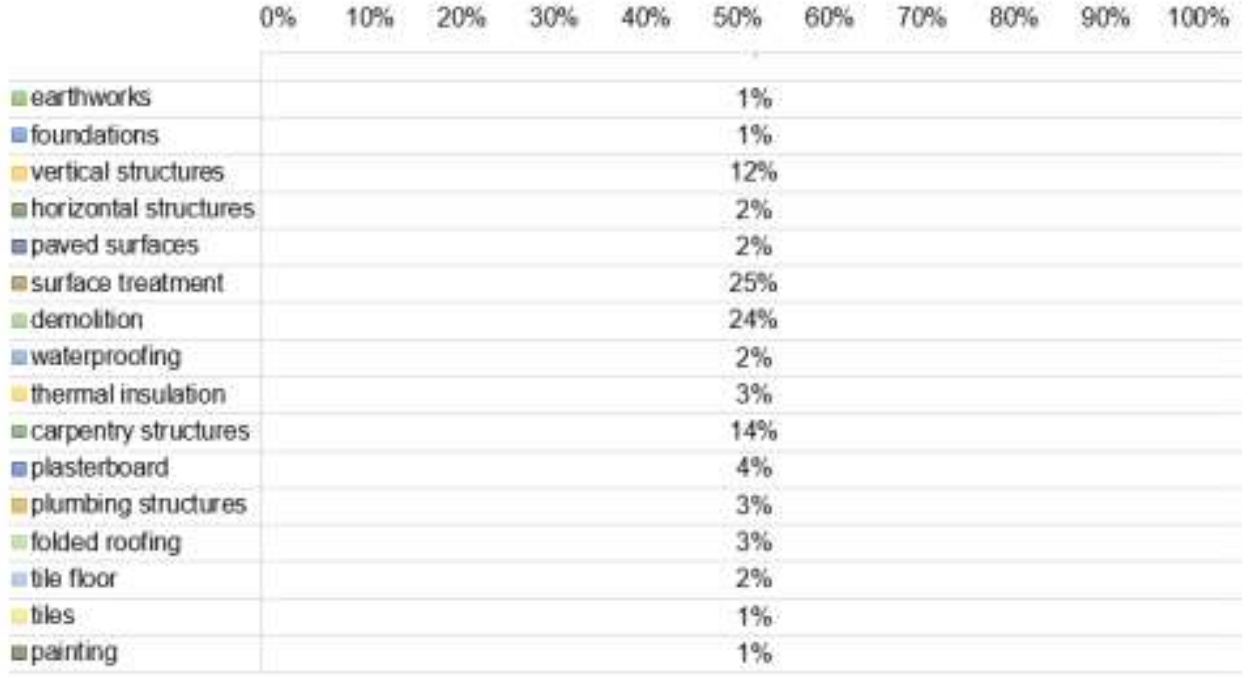

Figure 5. Composition of the compared sample showing the most frequently used items in the reconstruction of historical monuments

Source: Own processing.

Items of joinery and locksmith constructions do not occur in the examined sample. These are mainly construction works, including materials, which relate to the renovation and replacement of window openings, door leaves, gates, staircase structures, grilles, railings, etc. These structural elements are mainly estimated for construction work repairs and reconstructions of historic buildings and in the estimates are recorded as so-called Ritems. In the statistical file, bid prices and indicative prices were compared and the percentage difference between them was calculated for all items.

In the statistical file, the items of the HSV and PSV sections of the bid prices were compared with the indicative prices of the CS ÚRS price system. Based on the comparison, the percentage difference between them was calculated and the average determined.

The standard deviation was determined for the whole sample and subsequently also for the individual sections of HSV and PSV, a histogram was created with the frequency of occurrence for the following intervals:

- $\quad$ bid price (BP) is lower by more than $30.00 \%$ than indicative price (IP),

- $\quad$ BP is lower by $20.00-29.99 \%$ than IP,

- $\quad$ BP is $10.00-19.99 \%$ lower than IP,

- $\quad$ BP is $0.00 \%-9.99 \%$ lower than IP,

- $\quad \mathrm{BP}$ is higher by $10.00 \%-0.00 \%$ than IP,

- $\quad$ BP is higher by $10.01 \%-20.00 \%$ than IP,

- $\quad$ BP is higher by $20.01 \%-30.00 \%$ than IP,

- $\quad \mathrm{BP}$ is higher by more than $30.00 \%$ than IP

The arithmetic mean is the mean value of the examined sample. This is a statistical quantity of the position. Its definition is such that we add all the values of the statistical unit character and divide them by the number of these units. 


$$
\overline{\mathrm{x}}=\frac{1}{n} \sum_{i=1}^{n} x_{i}
$$

Where:

n... number of values in the statistical file,

$\mathrm{x} . .$. value of the statistical file,

$\overline{\mathrm{x}}$... average of the values of the statistical file.

The standard deviation determines how much the values are scattered or deviated from the average. It is defined as the square root of the variance. It can only take on positive values and has the same unit as the values in the statistical file. This is a statistical value characterizing variability.

$$
\sigma=\sqrt{\sigma^{2}}=\sqrt{\frac{1}{n}} \sum_{i=1}^{n}\left(x_{i}-\overline{\mathrm{x}}\right)^{2}
$$

Where:

$\sigma$... direct deviation,

$\sigma^{2}$. scatter,

$\mathrm{n} . .$. number of values in the statistical file,

$\mathrm{x} . .$. value of the statistical file,

$\overline{\mathrm{x}}$... average of the values of the statistical file.

The average difference between the bid prices and the indicative prices of the whole statistical sample is $-14.23 \%$. This means that, on average, bid prices are lower than the indicative prices. The standard deviation for the whole file was $15.35 \%$. The following figure shows the above-mentioned statistical quantities as well as a histogram of the frequency of occurrence for defined intervals.

Statistical sample ...... 464 items
Average .............. $\overline{\mathrm{x}}=-14.23 \%$
Standard deviation ..... $\sigma=15.35 \%$ 


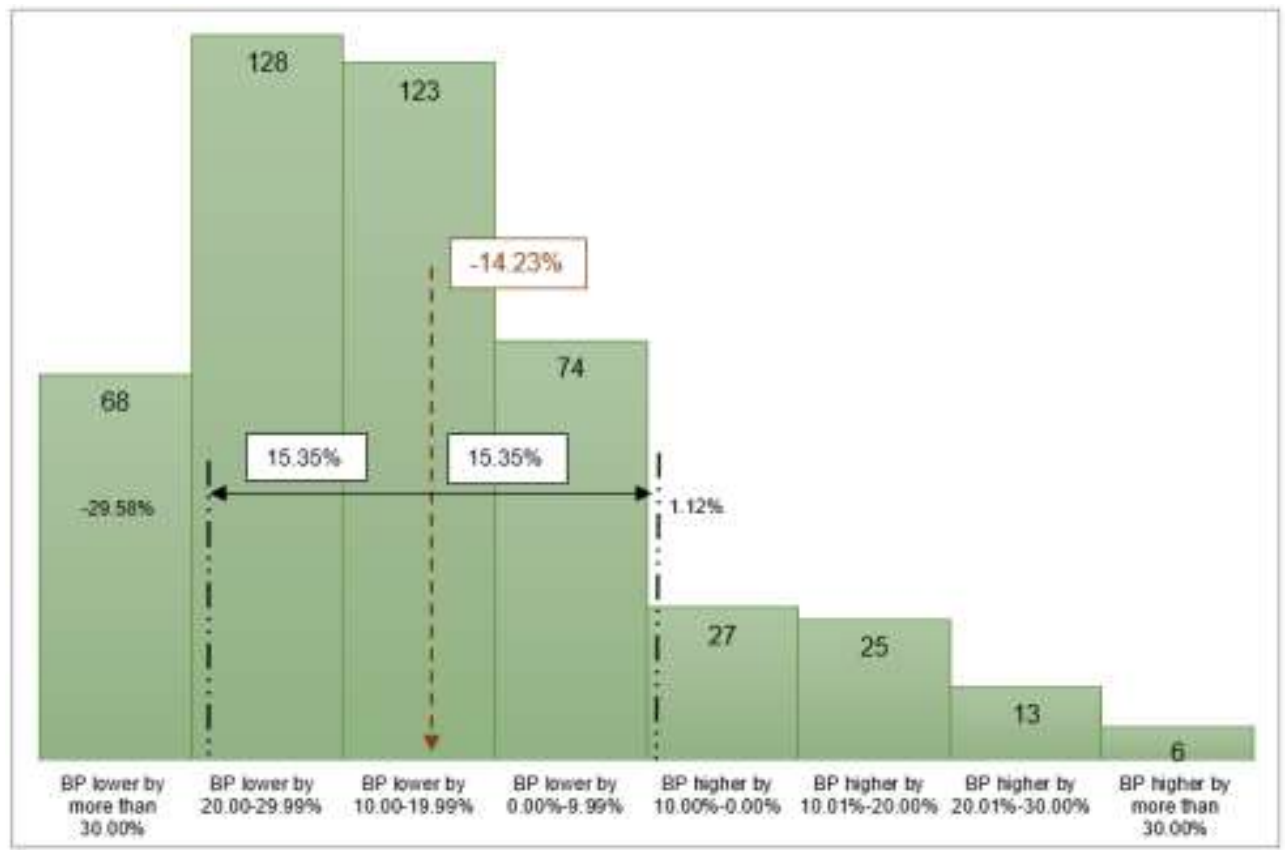

Figure 6. Statistics of the whole analyzed file Source: Own processing.

Among the examined sections, the most numerous were the vertical structures, surface modifications and demolition of structures, while in PSV (work trades) carpentry structures were the most common.

In the section of vertical construction, load-bearing foundation masonry, columns, walls, partitions, lintels and chimneys are valued. Repairs and maintenance include work related to, for example, walling of holes, replenishment of masonry, grouting of masonry, replenishment of cornice masonry, installation of rolled beams in prepared holes and related demolition work, which involves cutting out pockets for anchoring fasteners, etc. This section belongs to the more numerous ones in terms of the number of items in the examined set.

The average difference between the bid prices and the indicative prices of the statistical sample of vertical structures is $-9.61 \%$, i.e. on average, bid prices are lower than the indicative prices. The standard deviation of vertical structures is $15.83 \%$. The following figure shows the above-mentioned statistical quantities as well as a histogram of the frequency of occurrence for defined intervals.

Statistical sample 56 items

Average $\overline{\mathrm{x}}=-9.61 \%$

Standard deviation $\sigma=15.83 \%$ 


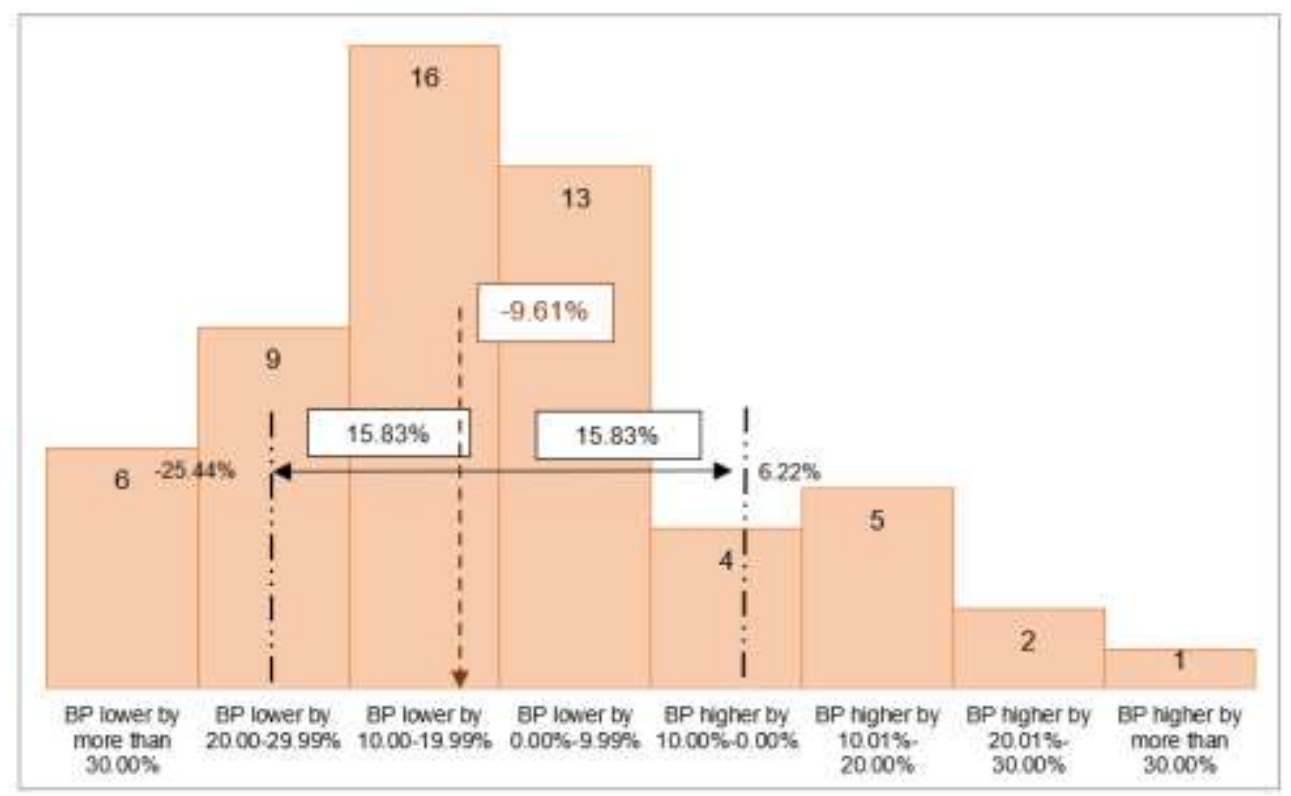

Figure 7. Statistics of vertical structures

Source: Own processing.

In this part, the construction works are divided into three larger groups, these are internal and external surface treatments and floor surface treatments such as floor embankments, screeds, anhydrites and cement screeds. In internal and external surface treatments, we find mainly plasters of walls, ceilings, columns and ceilings, as well as contact thermal insulation systems made of various materials. Among the items valuing repairs to historic buildings, the most common items are items for leveling uneven surfaces, repairing plasters of smaller areas and filling grooves.

The average difference between the bid prices and the indicative prices of the statistical sample of surface treatments is $-11.25 \%$. This means that, on average, bid prices are lower than the indicative prices. The standard deviation of surface treatments is $16.55 \%$. The following figure shows the above-mentioned statistical quantities as well as a histogram of the frequency of occurrence for defined intervals.

Statistical sample 118 items

Average $\overline{\mathrm{x}}=-11.25 \%$

Standard deviation $\sigma=-16.55 \%$ 


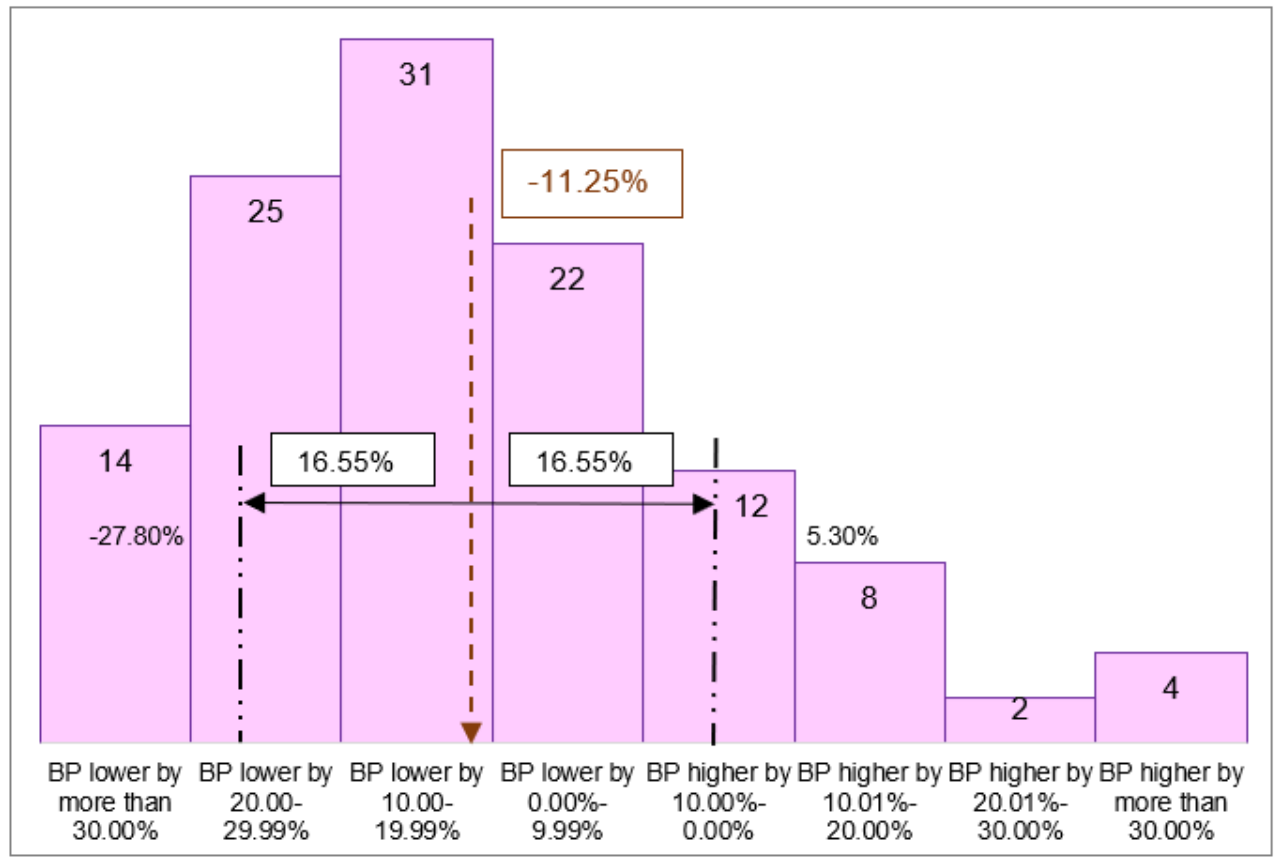

Figure 8. Surface treatment statistics

Source: Own processing.

The next most numerous group of items is the section of structures' demolition. The most common items were the demolition of masonry and partitions, loosening of beam heads, demolition of rolled beams, demolition of floors and subfloors, cutting of masonry and lining, cutting of pockets in masonry, fixing of ceilings, beating of interior and exterior plaster, demolition of window frames and masonry openings. , scraping joints in masonry, cutting tiles. This section also includes items valuing the removal of rubble and demolished materials to landfills.

The average difference between the bid prices and the indicative prices of the statistical sample of structural demolition is $-15.56 \%$. This means that, on average, bid prices are lower than the indicative prices. The standard deviation for the demolition of structures is $16.34 \%$. The following figure shows the above-mentioned statistical quantities as well as a histogram of the frequency of occurrence for defined intervals.

Statistical sample .111 items

Average $\overline{\mathrm{x}}=-15.56 \%$

Standard deviation $\sigma=16.34 \%$ 


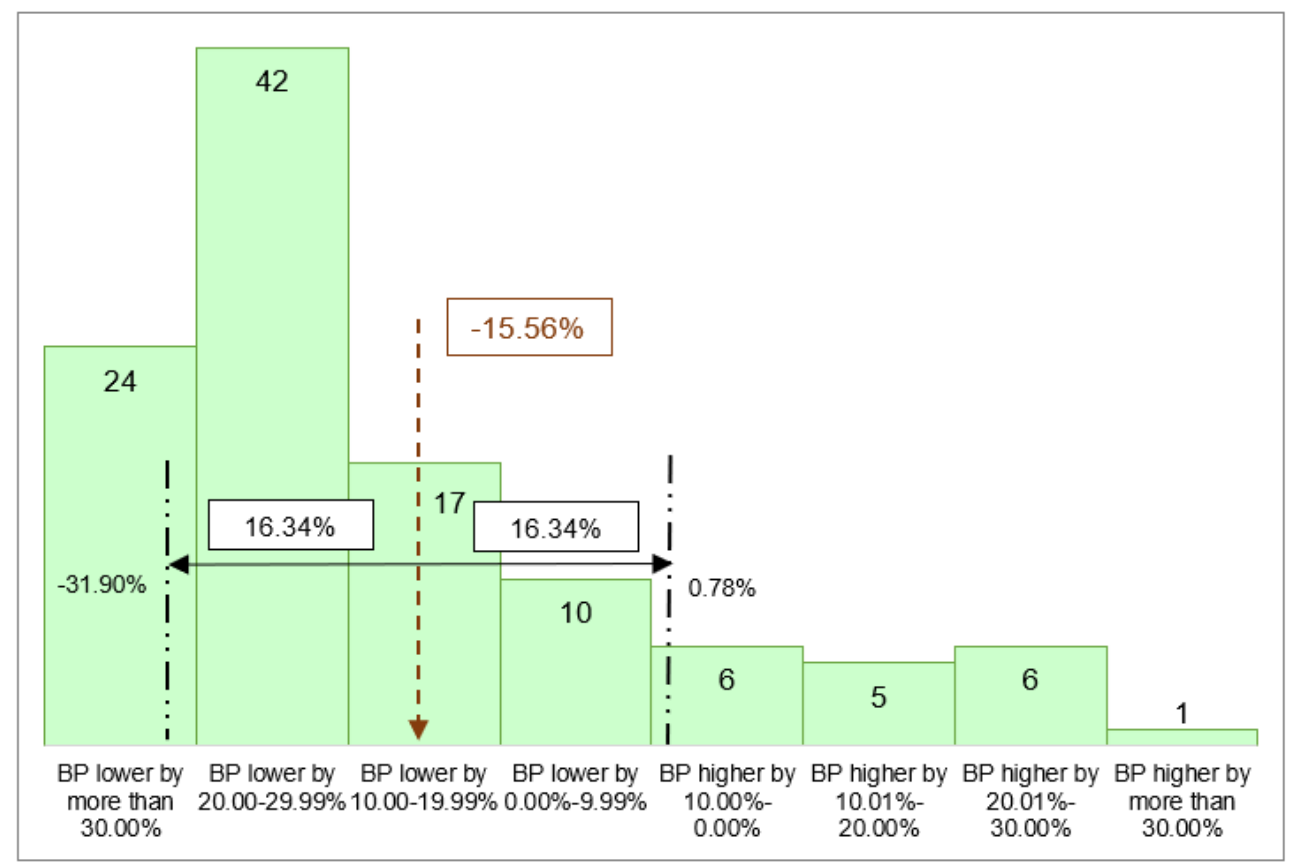

Figure 9. Statistics of demolition of structures

Source: Own processing.

Within carpentry constructions it is especially the assembly and disassembly of bound truss structures, battens and roof formwork which is being valued. Frequent items were carving, cutting out and completing the roof bond. In addition to roof structures, there are also items for dismantling and assembling floors from planks and wall cladding, laying cushions under the floors, cutting and completing ceiling beams.

The average difference between the bid prices and the indicative prices of the statistical sample of carpentry structures is $-16.95 \%$. This means that, on average, bid prices are lower than the indicative prices. The standard deviation for carpentry structures is $12.01 \%$. The following figure shows the above-mentioned statistical quantities as well as a histogram of the frequency of occurrence for defined intervals.

Statistical sample ..67 items

Average $\overline{\mathrm{x}}=-16.95 \%$

Standard deviation. $\sigma=12.01 \%$ 


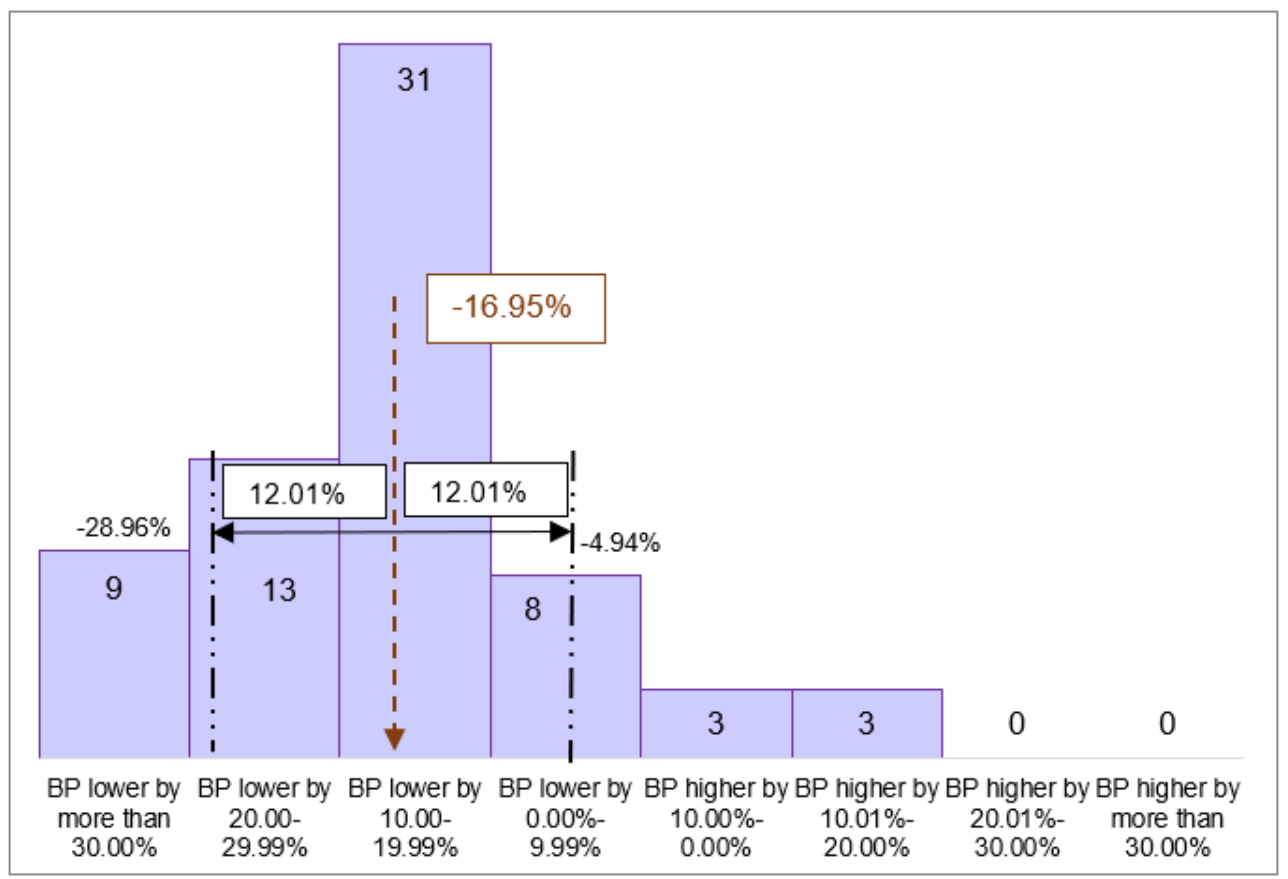

Figure 10. Statistics of carpentry structures

Source: Own processing.

\section{Results}

Valuation of reconstructions of historical buildings is quite problematic due to the nature of the works and an uncertainty in estimating their number. The aim of the indicative price analysis was to find out whether they actually correspond to prices on the construction market. It is necessary to realize that if the work on the building is subject to the restoration regime and can be performed only by a restorer with a valid permit, then it is necessary to value these works individually, because the indicative prices do not take restoration repairs into account. During reconstructions, you can also find a relatively large number of works that do not appear in the estimating software and are valued individually in the bids. These are mainly carpentry and locksmith constructions and artistic elements.

The price analysis was performed on a statistical sample of 464 items from 16 bid budgets. In comparison with the indicative prices of the CS URS price system in the price level I / 2021, the bid price was lower than the indicative price for $85 \%$ of the examined items.

A detailed percentage distribution of the differences between the bid and indicative prices can be seen in the following figure, when the bid price was $20.00-29.99 \%$ lower than the indicative price for $28 \%$ of the items. The average difference for all items in the sample was $-14.23 \%$. 


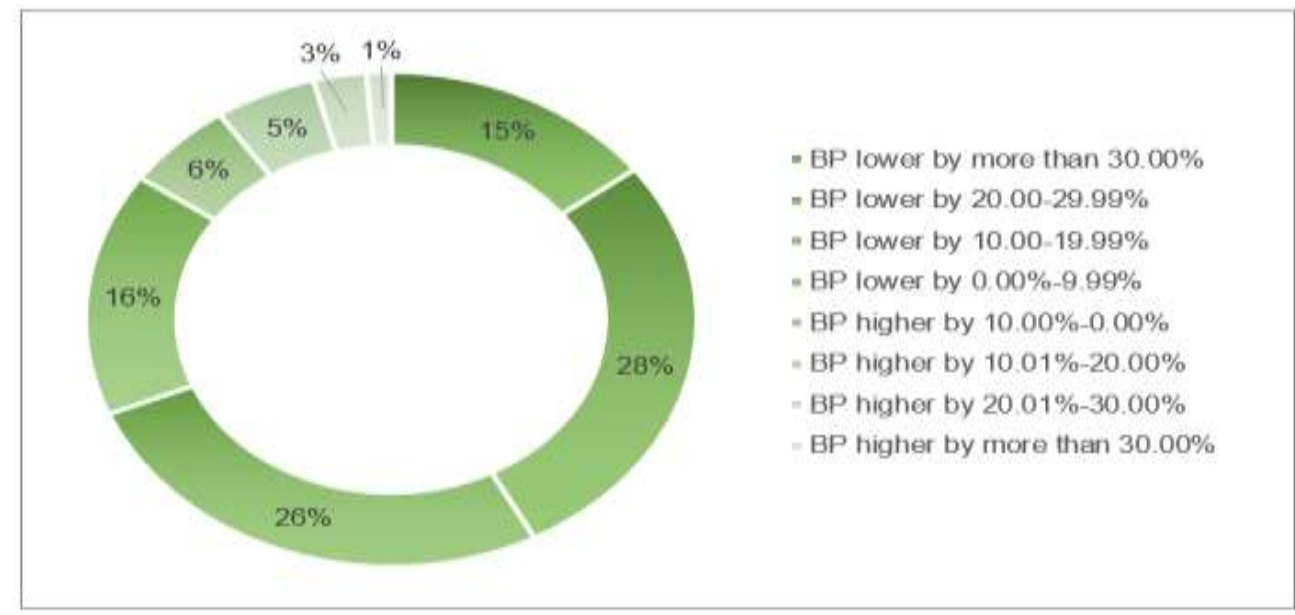

Figure 11. Percentage distribution of differences between bid and indicative prices

Source: Own processing.

Based on the performed analysis, valuation by indicative prices by the CS ÚRS price system for valuing reconstructions of historic buildings seems to be appropriate. When creating a bid price, it is always necessary to respect the specificity of a particular project and consider a possible adjustment of these prices. If the project includes restoration elements that are intended to be repaired by the restorer, these components must be valued separately.

\section{Conclusion}

The presented paper brings a methodology for the valuation of construction work in the reconstruction of historic buildings. The valuation method is based on an analysis of market prices for construction work used in historic buildings in combination with traditional pricing tools and methods. Based on the performed research, structural elements and technological units were identified for the specific sections. The unit price, which is assigned to these defined units, is based on the principle of sub-estimates and the CS ÚRS price system was used for its creation. The suitability of using this pricing system is based on the performed analysis and comparison of indicative and market prices on a statistical sample of 464 items from 16 bid budgets.

The proposed methodology is used in the follow-up application software MonuRev, where it is used for the valuation of the restoration and maintenance of selected immovable cultural monuments. The outputs of this application software can be used by the public sector in planning the restoration of immovable cultural heritage. The development of the MonuRev application is implemented within the NAKI II project of the Ministry of Culture. Ultimately, the application should be able to determine the cost of renovation and maintenance of historic buildings during the life cycle of buildings and enable investors to make relevant complex decisions and help reduce potential risks of such projects. 


\section{References}

1. M. Philokyprou, E. Limbouri-Kozakou, An overview of the restoration of monuments and listed buildings in Cyprus from antiquity until the twenty-first century. Studies in Conservation, 60(4), 267-277 (2014)

2. R. H. White, Editorial. The Historic Environment: Policy \& Practice, 7(4), 281-282 (2016)

3. B. Espion, R. Engels, M. Provost, Civil engineering heritage: country profile Belgium. Proceedings of the Institution of Civil Engineers - Engineering History and Heritage, 170(4), 197-205 (2017)

4. I. Sipiran, P. Lazo, C. Lopez, et al., Retrieval of cultural heritage objects. Computers \& Graphics, 100, 1-20 (2021)

5. J. Kęsik, M. Milosz, J. Montusiewicz, K. Samarov, Documenting the geometry of large architectural monuments using 3D scanning - the case of the dome of the Golden Mosque of the Tillya-Kori Madrasah in Samarkand. Digital Applications in Archaeology and Cultural Heritage, 22 (2021)

6. D. Fritsch, J. F. Wagner, B. Ceranski, S. Simon, M. Niklaus, K. Zhan, G. Mammadov, Making historical gyroscopes alive-2D and 3D preservations by sensor fusion and open data access. Sensors, 21(3) (2021)

7. E. Plebankiewicz, A. Leśniak, Overhead costs and profit calculation by polish contractors. Technological and Economic Development of Economy, 19(1), 141-16 (2013)

8. B. Bauer, J. Koppelhuber, J. Wall, D. Heck, Impact factors on the cost calculation for building services within the built environment. 3rd International Conference on Sustainable Civil Engineering Structures and Construction Materials - Sustainable Structures for Future Generations (SCESCM), 171, pp. 294-301 (2017)

9. R. Majer, H. Ellingerová, J. Gašparík, Methods for the calculation of the lost profit in construction contracts. Buildings, 10(4) (2020)

10. R. S. Heralová, Life cycle costing as an important contribution to feasibility study in construction projects. 6th Creative Construction Conference (CCC) In Procedia Engineering, 196, pp. 565-570 (2017)

11. D. Macek, Building maintenance and renovation. Conference on Central Europe towards Sustainable Building in Proceedings of the CESB 10: Central Europe towards Sustainable Building-From Theory to Practice, pp. 669-672 (2010)

12. J. Karásek, J. Pojar, L. Kaločai, R. S. Heralová, Cost optimum calculation of energy efficiency measures in the Czech Republic. Energy Policy, 123, 155-166 (2018)

13. R. S. Heralová, D. Macek, E. Hromada, I. Střelcová, L. Brožová, S. Vitásek, J. Pojar, R. Bouška, Cost optimization for renovation and maintenance of cultural heritage objects. IOP Conference Series: Earth and Environmental Science In: Central Europe towards Sustainable Building (CESB19), 290 (2019)

14. P. Dlask, V. Beran, Long-term infrastructure investment: a new approach to the economics location. E+M Ekonomie a Management, 19(3), 40-56 (2016)

15. D. Čápová, P. Dlask, O. Horák, P. Kalčev, Generace malých rozpočtů [Generations of small budgets]. Business \& IT, 8(2), 54-62 (2018)

16. J. Vrbka, P. Junga, T. Krulický, Methodology for determining the rate of return on rental of built-up land. Ad Alta-Journal of Interdisciplinary Research, 9(2), 364-370 (2019)

17. E. Hromada, R. S. Heralová, P. Dlask, T. Krulický, Methodology for calculating the reproduction value of buildings. EDP Sciences - Web of Conferences In: Innovative Economic Symposium 2020 - Stable Development in Unstable World (IES2020), 91 (2020) 
18. D. Macek, R. S. Heralová, E. Hromada, I. Střelcová, Cost optimization for renovation and maintenance of cultural heritage objects. IOP Conference Series: Earth and Environmental Science, 290 (2019)

19. R. Schneiderová, S. Vitásek, L. Brožová, I. Střelcová, Cost Estimating. Prague: Czech Technical University in Prague (2020)

20. Budgeter's handbook: Cost of construction works. Prague: ÚRS, Price system ÚRS (2017)

21. S. Vitásek, R. S. Heralová, Cost Estimating. Prague: Verlag Dashöfer (2018)

22. Software KROS 4 2021. Company ÚRS CZ 